\title{
Degree of Harmony of Urban Land Use and Economic Development: Case Study of Wuhan Metropolitan Area
}

\author{
Zhu Xiangbo ${ }^{1} \&$ Tan Shukui $^{1}$ \\ ${ }^{1}$ College of Public Administration, Huazhong University of Science and Technology, Wuhan, China \\ Correspondence: Tan Shukui, College of Public Administration, Huazhong University of Science and \\ Technology, Wuhan, China. Tel: 86-27-8755-9342.E-mail:tansk@126.com; zhuxiangbo@hotmail.com
}

\author{
Received: May 12, 2014 Accepted: May 27, 2014 Online Published: July 31, 2014 \\ doi:10.5539/jsd.v7n4p139 \\ URL: http://dx.doi.org/10.5539/jsd.v7n4p139
}

\begin{abstract}
As urban land use is facing more and more severe sustainability challenges, it is essential to make effective and scientific evaluation on relationship between urban land use and economic development. With a series of indicators that drawn from previous literatures and data collected from Wuhan Metropolitan Area, this paper evaluated the degree of harmony, which characterizes the level of sustainable in the eight cities. By methods of cluster analysis and grey rational analysis, degree of harmony was categorized and calculated. Results revealed that harmony degree of different cities had certain gaps which were continually widening and can be divided into four categories. Relative scores on harmony of them are almost consistency with the category. It is found that the difference on land use put significant on the degree of harmony. Some other characteristics including city administrative status, comparative regional advantages also have a large impact. These findings lead further suggestions and recommendations for governments to design relevant policy.
\end{abstract}

Keyword: Wuhan Metropolitan Area, degree of harmony, cluster analysis, gray relational analysis

\section{Introduction}

Urbanization promotes rapid social and economic development, but also leads to many problems, such as resource shortages and environmental pollution (Savard, Clergeau \& Mennechez, 2000; Van Herzele \& Wiedemann, 2003). The balance of economic growth, ecological construction, environmental protection, and social progress is thought of as the goal of sustainable urbanization. Neither sustainable statuses of any one, nor the simple sustainable status adding of them address sustainability (Riley, 2001). Methods that could mitigate or eliminate the problems were put forward by scholars and also carried out in some countries or districts to achieve sustainable development (Li et al., 2009; Shearer et al., 2006).

One of the main contexts of urbanization is the land use change. During this process, a large amount of natural and agricultural landscapes have been modified into construction or urban use fields in recently years and the tendency is expected to continue increasing (Attwell, 2000; Pauleit \& Duhme, 2000; Xiao et al., 2006). China is on the way of rapid urbanization, it is important for the policymakers to have the sustainability of urban land use. This paper aims to analyze the degree of harmony in the relationship between land use and economic development in Wuhan Metropolitan Area by establishing an alternative indicator framework. Based on the four indicators drawn from the previous literature, we further defined the harmonious relationship between land use and economic development, to gauge the extent of situation in Wuhan Metropolitan Area. Main parts of this research are organized into following sections. First, we present relevant studies to concern the research framework and indicators. This is followed by a brief outline of research methodology and data collection. Then, we classify and calculate the degree of harmony to make a comparative analysis. Finally, some strategies for achieving harmony relationship between land use and economic development are given with reference to the findings of the study.

\section{Literature Review}

Sustainable land use has become the research focus since the Brunt land report in the 1987 (WCED, 1987). Williams (2000) gave a definition of it based on the land use intensification. Due to the long history and special cultural background of China, the concept "Sustainability" is always substituted by the concept "Harmony"(Ye, Chen, \& Tu, 1999). Especially after the "Harmonious Society" was emphasized and formally proposed by the 
6th plenary of the 16th CPC central committee (2002). "Harmony" is the important goal which people are keen to achieve, and occupies an important place in cultures. The scientific research on "harmony theory" of Chinese scholars started with Xi and Wang (1989), they indicated the three main points of harmony theory and built a diagnostic system model to check the harmonious state in their research (Xi \& Wang, 1989).

Numerous of indicators used to measure the sustainability had been initiated within large research projects. Mori \& Christodoulou made a list of existing major sustainability indices/indicators including: Index of Sustainable Economic Welfare, City Development Index, Human Development Index (HDI), Environmental Vulnerability Index (EVI), Environmental Policy Index (EPI), Living Planet Index (LPI), Environmentally-adjusted Domestic Product (EDP), Genuine Saving (GS) and City Sustainability Index (CSI) (Mori \& Christodoulou, 2012).

On the evaluation of sustainable land use, Fu established a procedure and model of sustainable land use by selecting a series of indicators which reflect the quality, attributes and process of land use ( $\mathrm{Fu}$, Chen \& Ma, 1997). Meadows (1998) listed a framework of sustainable urban land use indicators that included technology, economy, politics and ethics. In the OECD indicator classification theme, the indicators were classified as Pressure or driving force categories (OECD., 2001). Ambiente Italia Research Institute designed 10 indicators(Tarzia, 2003) and Jacksonville Community Council selected 86 indicators based on the 15 criteria and nine objectives (Warner, 2006), while Meier and Wachter (2005) used five criteria to get about 30 indicators. Knights and Bowman (2007) chose 35indicators and divided these indicators into six categories, they also assigned weights. Brazzini-Mourier (2006) applied the decision-making tool and formed index with 39 indicators. After introducing an integrated indicators list, Shen et al. (2009) organized an index with 115 indicators, they named them as "International Urban Sustainability Indicators List (IUSIL)" and categorized into four dimensions (environmental, economic, social and governance). Similarly, other kinds of indexes system were formed with different number of indicators, like with 37indicators(Tomalty et al., 2007) and with 13 indicators (Cowley, Madden, Quinn \& Winter, 2007). Moles construct the sustainable index from the characteristics of urban land, including size, functionality and geographic location (Moles, Foley, Morrissey \& O'Regan, 2008).

Many methods were used in establishing evaluation model. Through summarizing case study experience, Bond, Curran, Kirkpatrick, Lee, and Francis (2001) developed a useable methodology for conducting integrated impact assessment. Peng, An, Chen, and Pu (2001) built the indicators, weights and target values of the sustainable index system and evaluate the present level of sustainable land use in the Yangtze River Delta in China. Reed, Fraser, and Dougill (2006) developed a methodological framework which offers a holistic approach for measuring progress towards sustainable development with integrating approaches from different paradigms. Xing, Horner, El-Haram, and Bebbington (2009) described how Sustainability Assessment Model (SAM) had been tailored for the construction industry and urban sustainability assessment.

The sustainability of urban land use and economic development were analyzed greatly during the particularly fast urbanization and industrialization in China. For example, the relationship between urbanization and land use change in Beijing (He, Shi, Chen \& Zhou, 2001), Shenzhen (Sui \& Zeng, 2001) and Guangzhou(Weng, 2002). Other research also made the comparative study, Van Dijk \& Mingshun (2005) measured the urban sustainability of four medium-sized Chinese cities (Qinhuangdao, Maanshan, Taizhou and Wuhai) and found that the social and the economic dimensions of urban sustainability make significant positive contributions to overall urban sustainability (Van Dijk \& Mingshun, 2005). Zhang (2011) finished an evaluation framework for sustainability of urban land use in capital cities and municipalities in China (X. Zhang, Wu \& Shen, 2011).

More research carried out in China on sustainability development with the aspect of "harmony" and the "degree of harmony". Countermeasures for harmonious urban land use were put forward. Xiong, Wen, and Guo (2006) studied the intrinsic relations between urbanization and land utilization by evaluating the overall land use structure, inner city land use and urban land use efficiency. Wang (2008) discussed the detail framework of "economic harmony" including principles, structure and approach, he established a Harmonious Evaluation Index (HEI) system and did an empirical quantitative study in China (Wang, 2008). Yin (2011) evaluated the degree of harmony between marine industry and social economy of the coastal provinces and cities of China (K. D. Yin \& Li, 2011).

The sustainable urban land use had been analyzed by many researchers. However, most of them were focused on the conceptual framework and strategies of sustainable urban land use, the quantitative and empirical analysis should strengthen. In addition, studies were main carried out at the city level and few of them addressed the sustainability of urban land use in the region. With the development of harmony theory, it is easier to give a precise definition of degree of harmony. This paper will make comprehensive application of cluster analysis and 
gray relational analysis to study the harmony between land use and economic development, choosing Wuhan Metropolitan Area as an example. By applying these methods, the results of this paper will not only overcome the limitations of using a single method to establish index system but also provide criteria to evaluate the harmonious development of land use and economic development.

\section{Introduction of the Study Area and Data Collection}

\subsection{Introduction of the Study Area}

Wuhan Metropolitan Area is located in Hubei province and in the middle of the Yangtze River basin, whose population is concentrated in urban areas, with better opportunities for economic development and strong infrastructure. It contains Wuhan along with eight cities, including Huangshi, Ezhou, Huanggang, Xiaogan, Xianning, Xiantao, Qianjiang and Tianmen. All these cities are surrounding the area within a $100 \mathrm{~km}$ radius of Wuhan, so this metropolitan area is also called " $1+8$ ". This area covers $33 \%$ of the total land and $51.6 \%$ population of Hubei province. In 2013, the total output value of Wuhan Metropolitan Area reached 1.260858 trillion Yuan, accounting for $63.2 \%$ GDP, $65.3 \%$ of the all levels fiscal revenue, $63.4 \%$ of investment and $62.5 \%$ of the total volume of retail sales of Hubei province. Wuhan Metropolitan Area has the best production elements and is the most economically vital area. Compared with other region, this area had the significant superiority on industry foundation capital stock. The proportions of primary, secondary and tertiary industry was 9.8:49.5:40.7 in 2012. Wuhan is one of the three scientific and education centers of China, along with Beijing and Shanghai. The geographic location is shown in Figure 1 (see below).

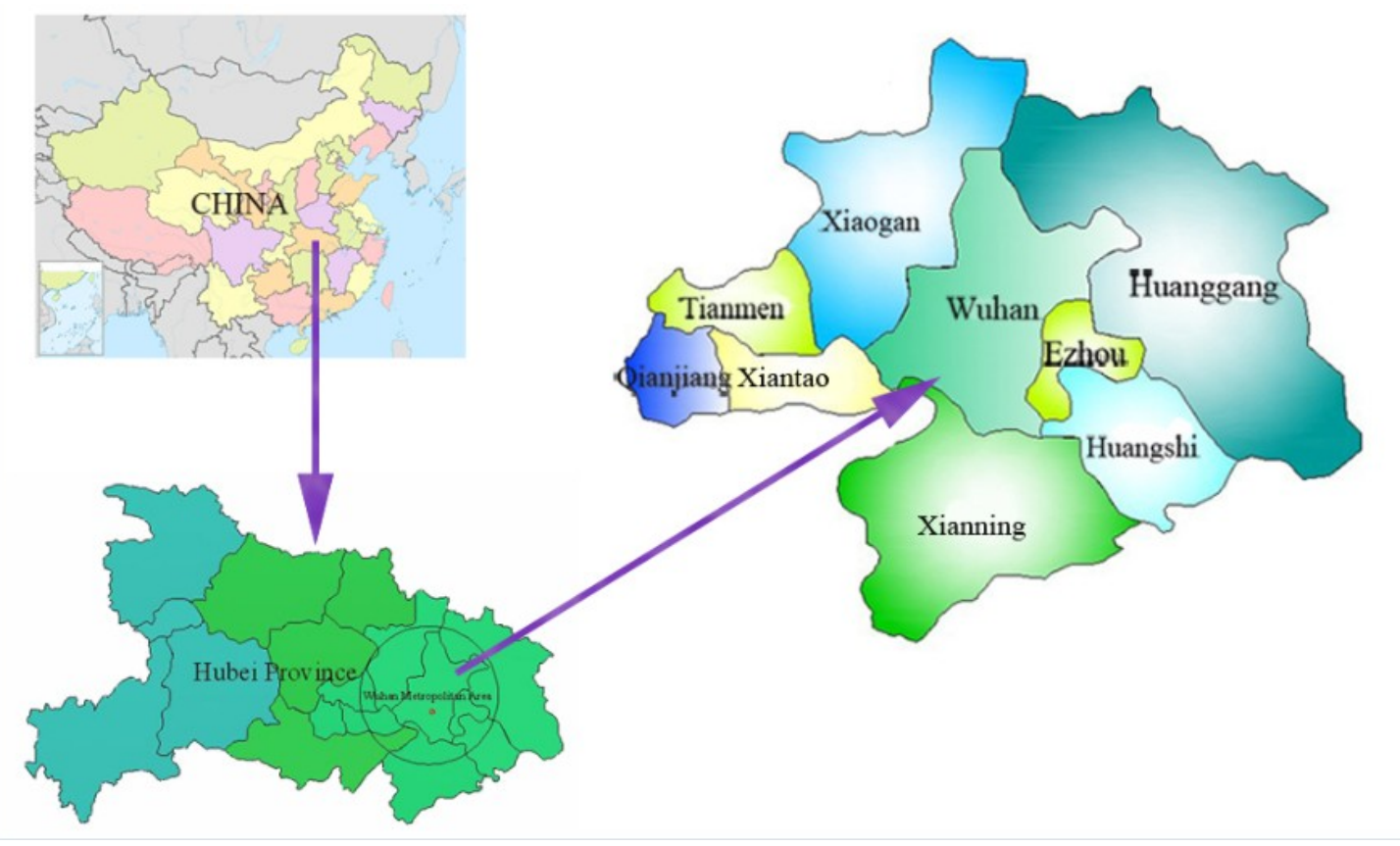

Figure 1. Geographical position of Wuhan Metropolitan Area

Source: Draw by author

Selected as a comprehensive reform pilot area by State Council and National Development and Reform Commission of China in 2007, Wuhan Metropolitan Area should find new strategies of urbanization to achieve "Resource conservation and environmental friendliness". Although there are neither additional preferential policies nor financial incentives, local governments of this area acquire the right to adopt flexible policies. It is a good opportunity for authorizes to get sustainable development and urban land use. Now Wuhan Metropolitan Area is the strongest developmental engine in the area and plays an important role in the development of Hubei province and the rise of central China.

\subsection{Indicators Selection and Data Pretreatment}

Many common standards were found in design indicators, at least two points. First, indicators consider economic, social and environmental components as well as the overlaps between them. Second, the objectives of indicator system should reflect the existing tradeoffs between the considerations of specific factors for each city or 
municipality and the need to homogenize the indicators(Button, 2002; Repetti \& Desthieux, 2006). For the research focus of this paper was economic development, after scientifically considering the harmony theory and the situations of Wuhan Metropolitan Area, we designed the indicators system with four themes: intensive utilization of land use, land market development status, land use structure and sustainable land use situation. The reasons of this choice were put follows: (1) Efficiency of harmony of land use and economic development, which are mainly reflected as the intensive utilization of land use, the intensive use level, density of output value and level of regional development. Per land GDP referred to as GDP is calculated in accordance with land, it is a good indicator to reflect the land use efficiency. It is widely used to evaluate the regional development disparities. Yin et al (2002) compared the evaluation results respectively got from Per land GDP and Per Capita GDP with the data collected from Guangdong province (L. Yin, Feng, \& Li, 2012). (2) Comprehensive land price reflects the urban land price level calculated from the arithmetic mean value of commercial land, residential land and industrial price level, while the average real estate price was a perfect indictor to show the land use development. If the real estate market is developing steadily, it represents that the land use is harmonious. (3) Structuring harmony of land use and economic development, investment is the important engine of the development. We use real estate as the carrier of land to measure the contribution of land elements in the economy development. Harmony development of economic should be promoted by more elements. (4) Sustainable harmony of land use and economic development. Sustainable development is one of the most important parts in future cities. The properties and sources of evaluation index system are listed in Table 1.

Table 1. Evaluation index system of harmony between land use and economic development

\begin{tabular}{|c|c|c|}
\hline Chat & Indicator & Source \\
\hline $\begin{array}{l}\text { Efficiency harmony of land use } \\
\text { and economic development }\end{array}$ & $\begin{array}{l}\text { Relative index of urban land output } \\
\text { efficiency and economic development } \\
\text { efficiency }\end{array}$ & Per \\
\hline $\begin{array}{l}\text { Structure harmony of land use } \\
\text { and the real estate development }\end{array}$ & $\begin{array}{l}\text { Relative index of the land market } \\
\text { development and real estate market } \\
\text { development }\end{array}$ & $\begin{array}{l}\text { The city's comprehensive land } \\
\text { price/real estate sales average price }\end{array}$ \\
\hline $\begin{array}{l}\text { Structure harmony of land use } \\
\text { and economic development }\end{array}$ & $\begin{array}{l}\text { Relative index of Land use and economic } \\
\text { development structure }\end{array}$ & $\begin{array}{l}\text { Real estate investment/fixed assets } \\
\text { investment }\end{array}$ \\
\hline $\begin{array}{l}\text { Sustainable harmony of land use } \\
\text { and economic development }\end{array}$ & $\begin{array}{l}\text { Relative index of Land use and economic } \\
\text { sustainable development }\end{array}$ & $\begin{array}{l}\text { Use population density as an } \\
\text { alternative index value }\end{array}$ \\
\hline
\end{tabular}

Data for selected variables were collected from "Statistical yearbook of Hubei province (2011 2013)", "China's urban statistical yearbook (2011 2012)". And the city's comprehensive land price and house price data is collected from the "City land price monitoring report of Hubei Province" (2012 annual). The social and economic statistic data of Wuhan Metropolitan Area were put in the appendix. With the definition of indicators list above, we calculated the value of them. For the dimension difference, we applied the liner transformation to process origin data as standardization. The results of the pretreatment are shown in the Table 2(see below). 
Table 2. The data of the evaluation index system of Wuhan Metropolitan Area (2012)

\begin{tabular}{ccccc}
\hline & $\begin{array}{c}\text { Per land } \\
\text { GDP }\end{array}$ & $\begin{array}{c}\text { City's comprehensive land price/real } \\
\text { estate sales average price }\end{array}$ & $\begin{array}{c}\text { Real estate investment/fixed } \\
\text { assets investment }\end{array}$ & $\begin{array}{c}\text { Population } \\
\text { density }\end{array}$ \\
\hline Wuhan & 0.11 & 0.45 & 0.26 & 1.07 \\
Huangshi & 0.05 & 0.17 & 0.09 & 0.53 \\
Ezhou & 0.06 & 0.24 & 0.04 & 0.65 \\
Xiaogan & 0.05 & 0.17 & 0.08 & 0.53 \\
Huanggang & 0.04 & 0.31 & 0.07 & 0.38 \\
Xianning & 0.03 & 0.25 & 0.13 & 0.26 \\
Xiantao & 0.05 & 0.27 & 0.04 & 0.49 \\
Qianjiang & 0.05 & 0.30 & 0.03 & 0.47 \\
Tianmen & 0.05 & 0.41 & 0.05 & 0.52 \\
\hline
\end{tabular}

\section{Research Methods and Process}

\subsection{Cluster Analysis}

By application of cluster analysis, the set of data can be classified into different group. In order to keep the accuracy and reliability of the classification, the data was converted to standard by a "Z-scores" method. Then the author used the Ward Method deviation square Method (Euclidian distance) for clustering and selected four categories. All these process were finished in SPSS and results are shown in the table 3.

Table3. Cluster analysis result of land use and economic development degree of harmony

\begin{tabular}{llllllllll}
\hline City & Wuhan & Huangshi & Ezhou & Xiaogan & Huanggang & Xianning & Xiantao & Qianjiang & Tianmen \\
\hline Class & 1 & 3 & 3 & 3 & 2 & 2 & 4 & 4 & 4 \\
\hline
\end{tabular}

From the results of clustering analysis, we divided the cities of Wuhan Metropolitan Area into four classes. Wuhan is alone in a class; Huangshi, Ezhou and Xiaogan are categorized together in a class; Xianning and Huanggang are together in a class and left for a class. In order to check the significance of cluster analysis, one-way ANOVA were applied. According to the P-value, all variables passed the $10 \%$ level significance test. Four variables of evaluation index system are significant, although variable that valued the Relative index of the land market development and real estate market development is weaker. Results of the one way ANOVA was shown in Table 4.

Table4. One way ANOVA results of degree of land use and economic development

\begin{tabular}{lcc}
\hline \multicolumn{1}{c}{ Variable } & P-Value & Significant \\
\hline Relative index of urban land output efficiency and economic development efficiency & 0.001 & YES \\
Relative index of the land market development and real estate market development & 0.046 & YES \\
Relative index of Land use and economic development structure & 0.006 & YES \\
Relative index of Land use and economic sustainable development & 0.001 & YES \\
\hline
\end{tabular}

\subsection{Relational Analysis}

We used grey Relational Analysis to calculate the degree of harmony. Grey Relational Analysis is a method used for quantitative description and to compare the development and changing trends in the system. It is always used to analyze a system that contains multiple influencing factors. The results can show the influence degree and influence direction of each factor.

1) Initialization (or Equalization) processing of original data 
Take $x_{1}, x_{2}, \ldots x_{n}$ as the factors of system, and then the data sequences that show the characteristics of each factor follow as such:

$$
\left\{x_{1}(t)\right\},\left\{x_{2}(t)\right\}, \ldots,\left\{x_{n}(t)\right\}(\mathrm{t}=1,2, \ldots, \mathrm{M} ; M \leq N)
$$

While:

$$
x i^{\prime}(t)=\frac{x_{i}(t)}{x_{1}(t)}, x i^{\prime}(t)=\frac{x_{i}(t)}{\overline{x_{i}}} \quad(\mathrm{i}=1,2, \ldots, \mathrm{N} ; \mathrm{t}=1,2, \ldots, \mathrm{M})
$$

Results of this step were shown in the table 5 .

Table 5. Equalization results of the original data

\begin{tabular}{cccccccccc}
\hline$x_{n}(t)$ & Wuhan & Huangshi & Ezhou & Xiaogan & Huanggang & Xianning & Xiantao & Qianjiang & Tianmen \\
\hline $\begin{array}{c}\text { Per land GDP } \\
\quad \text { City's }\end{array}$ & 0.23 & 0.25 & 0.26 & 0.25 & 0.19 & 0.15 & 0.24 & 0.22 & 0.20 \\
$\begin{array}{c}\text { comprehensive land } \\
\text { price/real estate } \\
\text { sales average price } \\
\begin{array}{c}\text { Real estate } \\
\text { investment/fixed } \\
\text { assets investment }\end{array}\end{array}$ & 0.96 & 0.79 & 0.98 & 0.80 & 1.55 & 1.50 & 1.28 & 1.41 & 1.59 \\
Population density & 2.27 & 0.45 & 0.15 & 0.39 & 0.34 & 0.80 & 0.19 & 0.14 & 0.20 \\
\hline
\end{tabular}

2) Calculate difference sequence $\Delta_{i}(t)$

Used the results of first step, we got the difference sequence of variables and put in the table 6 .

Table 6. Difference sequence results of variables

\begin{tabular}{cccccccccc}
\hline Difference sequence & Wuhan & Huangshi & Ezhou & Xiaogan & Huanggang & Xianning & Xiantao & Qianjiang & Tianmen \\
\hline $\begin{array}{c}\text { Per land GDP } \\
\text { City's }\end{array}$ & 0.16 & 0.13 & 0.12 & 0.13 & 0.19 & 0.23 & 0.14 & 0.16 & 0.18 \\
$\begin{array}{c}\text { comprehensive land } \\
\text { price/real estate } \\
\text { sales average price }\end{array}$ & 0.08 & 0.25 & 0.06 & 0.24 & 0.51 & 0.46 & 0.24 & 0.37 & 0.55 \\
$\quad \begin{array}{c}\text { Real estate } \\
\text { investment/fixed } \\
\text { assets investment }\end{array}$ & 0.14 & 0.25 & 0.55 & 0.30 & 0.36 & 0.10 & 0.50 & 0.56 & 0.49 \\
Population density & 0.38 & 0.63 & 0.73 & 0.66 & 0.04 & 0.34 & 0.41 & 0.35 & 0.13 \\
\hline
\end{tabular}

3) Calculate $\Delta \min$ and $\Delta \max$

During the evaluation process, some measurements should be noticed, Practicality on the reference sequence choosing of four variables. For the relative index of urban land output efficiency and economic development efficiency, the optimum value (0.23) among nine cities was chosen. Generally speaking, the land price account for about $30 \%$ of housing price, this paper applied 0.3 as the reference sequence for relative index of the land market development and real estate market development (Altuzarra \& Esteban, 2011; Gallin, 2008; Weida, 2005; Wen \& 
Goodman, 2013). From some statistical data and research report, it is found that the real estate investment accounted for nearly $20 \%$ of the total social fixed assets investment of China in last decade (2003-2012). We took 0.2 as reference sequence of Relative index of Land use and economic development structure.

4) Calculate relational index

$$
\xi_{i}(t)=\frac{\Delta \min +k \Delta \max }{\Delta_{i}(t)+k \Delta \max }(t=1,2, \ldots M)
$$

$k$ is the discrimination coefficient of Grey relationship analysis and is a constant while $k \in(0,1)$. Previous research proved that the smaller the $\mathrm{k}$ is the higher discrimination it has (Mao, 2003; Yeh \& Chen, 2014 ; Q. Zhang, Xing, Liu, \& Huang, 2014). We choose three different conditions when $\mathrm{k}=0.2, \mathrm{k}=0.3$ and $\mathrm{k}=0.5$, but the results of grey relational analysis were very similar and consistent. So we selected $\mathrm{k}=0.2$ to continue the research and explanation.

5) Calculate relational degree

$$
\gamma_{i} \approx \frac{1}{M} \sum_{t=1}^{M} \xi_{i}(t)
$$

Based on the step from 1 to 4, we calculate the relational degree and make a sort of the results. In order to make a more clear description, the degree of harmony of the first city was scored as 90 , and then the scores of other cities were calculated. All results have shown in Table 7.

Table 7. The results of grey relational analysis and sort of cities

\begin{tabular}{cccc}
\hline City & Result of grey relational analysis & Result of sort & Score of relative degree of harmony \\
\hline Wuhan & 0.6012 & 1 & 90 \\
Huangshi & 0.4610 & 5 & 69 \\
Ezhou & 0.5189 & 3 & 78 \\
Xiaogan & 0.4513 & 6 & 68 \\
Huanggang & 0.5509 & 2 & 82 \\
Xianning & 0.4822 & 4 & 72 \\
Xiantao & 0.4355 & 8 & 65 \\
Qianjiang & 0.401 & 9 & 60 \\
Tianmen & 0.4492 & 7 & 67 \\
\hline
\end{tabular}

The degree of harmony in Wuhan Metropolitan Area is divided into four levels and the gaps between cities were widening. It is found that the cluster analysis and gray relational analysis are consistent with each other. Those cities that were categorized together in a class had similar level on degree of harmony. Wuhan had the highest degree while Xiantao, Qianjiang and Tianmen rowed in the last.

\section{Results Analysis}

1) Wuhan. As the capital of Hubei province and the center of Wuhan Metropolitan Area, Wuhan has significant advantage and strength of development. It is one of the three scientific and education centers of China and had the largest number of enrolled college students in the world in 2011. In addition, Wuhan had a good structure of major industries, such as optic-electronic, automobile manufacturing, steel manufacturing, new pharmaceutical sector, biology engineering and new materials industry. The main way of industry land use are development zones (parks), there are three national development zones and four scientific and technologic development parks. These advantage on social, economic and technologic conditions put significant positive influence on the urban land use sustainability. The relationship between land use and economic development can be more harmonious with the adjustment and improvement in industry.

2) Ezhou, Huangshi, Xiaogan. In the cluster analysis, these three cities were divided into a category. At same time, the relative harmony score got from Grey Rational Analysis of them are similar. Ezhou, Huangshi and Xiaogan are 
located next to Wuhan city and own relatively similar economic conditions, they belonged to the core layer of Wuhan Metropolitan Area. Ezhou is the smallest prefecture-level city in Hubei province and located nearest Wuhan, it undertake many industrial transfers from Wuhan and also the main leisure destinations of Wuhan. With the advantage of Backwardness and good urban planning, Ezhou has a relatively high degree of harmony on the urban land use. Huangshi is the traditional industrial base of Wuhan and has strong infrastructure thanks to industrial development in the city. The level of sustainable development is very low in this city. But because Huangshi was selected as the "Resource Exhausted City", it has many opportunities to make high technological developments and environmentally friendly industrial development that will improve the degree of harmony between land use and economic development. Xiaogan is located near Wuhan and has the largest administrative area. Its industrial level is the lowest between the three cities. With a large land area and balanced environmental conditions, Xiaogan has the highest level of the index of land use and economic development for sustainable development in the city. And it has a high degree of harmony between land use and economic development.

3) Huanggang and Xianning. These cities are located at the peripheral layer of the Wuhan Metropolitan Area and have a lot of free undeveloped spaces. Agriculture is the primary contributor to the GDP of both of these cities. But the degree of harmony is in good condition. Huanggang is ranked as second. It has long history of its development during the Chinese revolution from 1920 to 1950s. The city contains natural resources and a rich culture, and potentially has enough resources to meet the demands of the future. Xianning is called the "park" of Wuhan Metropolitan Area because it has the best natural environment among all cities. From our analysis, the index of land use and economic development structure is very high thanks to good opportunities for investment in real estate. With the capacity of having a good natural environment enriched with natural resources, Xianning has the potential to build a good harmony in the future.

4) Xiantao, Qianjiang, Tianmen. They are together in a class and considered the bottom layer of the Wuhan Metropolitan Area. These cities have harmonious degree and are among the lowest among of cities by their degree of harmony in Wuhan Metropolitan Area. These cities have administrative regions at their county level and have similar levels of natural resources.

\section{Discussions}

The relationship will become more complex under the drastic changes in social and economic conditions of the cities. This research has many shortages. As the author selected the efficiency of real estate (residential, industrial real estate and commercial real estate) to measure land use, it has limitations and need to be expanded. In addition, this research applied simple econometric models to finish analysis and locked on the calculation of the relationship between different variables and methods. Furthermore, all cities of Wuhan Metropolitan Area belong to only the Hubei province. The study area does not have any conflicts of interest regarding their economic development, land use, structure of the administration or system. If we selected any other area for research it may have produced different and conflicting results.

With the rapid urbanization and industrialization, the imbalance between human activities and land resources is continually rising $(\mathrm{Su}, 2009)$. The harmonious relationship between land use and economic development in cities is very significant for the proper utilization of land resources, equal economic development, and the attainment of sustainable development in the region. Increasing the degree of harmony on urban land use and economic development requires authorities to have more cooperation. First, establish a regional cooperation organization to integrate the land resource. Second, formulate integration plan which including industry plan, urban land use plan. Third, promote more sustainable use of the ecosystem. All these are the necessary way to develop a more harmony situation on urban land use.

\section{Conclusions}

Degree of harmony between land use and economic development is very complex. Based on scientific analysis, we came to our conclusions as follows:

1) The relationship between land use and economic development is overall harmonized in the Wuhan Metropolitan Area. But according to some set standards, the harmonious degree has to go a long way to reach the standards of the well-developed city circles of the country.

2) Levels of harmony between land use and economic development have a certain gaps between cities that are widening with the passage of time. As the center of the Wuhan Metropolitan Area, Wuhan has a relatively high primacy index as compared to other cities of the circle and it assists other cities in their economic development. On the other hand, Wuhan is also snatching the resources of the other cities of the circle for its own economic development. 
3) Besides economic development and land use, the degree of harmony is affected by other several factors like the administrative level of the city, the geographical location in the circle, the industrial structure of the city, population growth and dynamics and the use of technology etc.

\section{References}

Altuzarra, A., \& Esteban, M. (2011). Land prices and housing prices: the case of Spain. Journal of Housing and the Built Environment, 26(4), 397-409. http://dx.doi.org/10.1007/s10901-011-9235-8

Attwell, K. (2000). Urban land resources and urban planting — case studies from Denmark. Landscape and Urban Planning, 52(2), 145-163. http://dx.doi.org/10.1016/S0169-2046(00)00129-8

Bond, R., Curran, J., Kirkpatrick, C., Lee, N., \& Francis, P. (2001). Integrated impact assessment for sustainable development: a case study approach. World Development, 29(6), 1011-1024. http://dx.doi.org/10.1016/S0305-750X(01)00023-7

Brazzini-Mourier, S. (2006). Indicators communaux intégrés. Rapport de synthèse. Onex, Genève: Ville d'Onex.

Button, K. (2002). City management and urban environmental indicators. Ecological economics, 40(2), 217-233. http://dx.doi.org/10.1016/S0921-8009(01)00255-5

Cowley, C., Madden, P., Quinn, T., \& Winter, T. (2007). The sustainable cities index: Ranking the largest 20 British cities. Paper presented at the London, UK: Forum for the future organisation.

Fu, B., Chen, L., \& Ma, C. (1997). The index system and method of land sustainable use evaluation. Journal of natural resources, 12(2), 112-118.

Gallin, J. (2008). The Long-Run Relationship Between House Prices and Rents. Real Estate Economics, 36(4), 635-658. http://dx.doi.org/10.1111/j.1540-6229.2008.00225.x

He, C.-Y., Shi, P.-J., Chen, J., \& Zhou, Y. (2001). A study on land use/cover change in Beijing area. Geographical Research, 20(6), 679-687.

Knights, C., \& Bowman, S. (2007). Canada's most sustainable cities. Special report of March, 6, 2007.

Li, F., Liu, X., Hu, D., Wang, R., Yang, W., Li, D., \& Zhao, D. (2009). Measurement indicators and an evaluation approach for assessing urban sustainable development: A case study for China's Jining City. Landscape and Urban Planning, 90(3-4), 134-142. http://dx.doi.org/10.1016/j.landurbplan.2008.10.022

Mao, X. S. (2003). Letermination of discrimination coefficient in grey incidence analysis. Journal of Air Force Engineering University (Natural Science Edition), 1(4), 68-70.

Meadows, D. H. (1998). Indicators and information systems for sustainable development. Sustainability Institute Hartland.

Meier, A., \& Wachter, D. (2005). Indicators centraux pour le développement durable des villes et cantons. Rapport du Cercle Indicateurs. Berne, Switzerland: Office fédéral du développement territorial.

Moles, R., Foley, W., Morrissey, J., \& O'Regan, B. (2008). Practical appraisal of sustainable development-Methodologies for sustainability measurement at settlement level. Environmental Impact Assessment Review, 28(2-3), 144-165. http://dx.doi.org/10.1016/j.eiar.2007.06.003

Mori, K., \& Christodoulou, A. (2012). Review of sustainability indices and indicators: Towards a new City Sustainability Index (CSI). Environmental Impact Assessment Review, 32(1), 94-106. http://dx.doi.org/10.1016/j.eiar.2011.06.001

OECD. (2001). Environmental indicators for agriculture: Methods and results. OECD.

Pauleit, S., \& Duhme, F. (2000). Assessing the environmental performance of land cover types for urban planning. Landscape and Urban Planning, 52(1), 1-20. http://dx.doi.org/10.1016/S0169-2046(00)00109-2

Peng, B., An, X., Chen, F., \& Pu, L. (2001). A study on sustainable land use in the Yangtze River Delta. Journal of natural resources, 16(4), 305-312.

Reed, M. S., Fraser, E. D. G., \& Dougill, A. J. (2006). An adaptive learning process for developing and applying sustainability indicators with local communities. Ecological economics, 59(4), 406-418. http://dx.doi.org/10.1016/j.ecolecon.2005.11.008

Repetti, A., \& Desthieux, G. (2006). A Relational Indicatorset Model for urban land-use planning and management: Methodological approach and application in two case studies. Landscape and Urban Planning, 77(1), 196-215. http://dx.doi.org/10.1016/j.landurbplan.2005.02.006 
Riley, J. (2001). Indicator quality for assessment of impact of multidisciplinary systems. Agriculture, ecosystems \& environment, 87(2), 121-128. http://dx.doi.org/10.1016/S0167-8809(01)00272-9

Savard, J.-P. L., Clergeau, P., \& Mennechez, G. (2000). Biodiversity concepts and urban ecosystems. Landscape and Urban Planning, 48(3), 131-142. http://dx.doi.org/10.1016/S0169-2046(00)00037-2

Shearer, A. W., Mouat, D. A., Bassett, S. D., Binford, M. W., Johnson, C. W., \& Saarinen, J. A. (2006). Examining development-related uncertainties for environmental management: Strategic planning scenarios in Southern California. Landscape and Urban Planning, 77(4), 359-381. http://dx.doi.org/10.1016/j.landurbplan.2005.04.005

Shen, Q., Chen, Q., Tang, B.-S, Yeung, S., Hu, Y., \& Cheung, G. (2009). A system dynamics model for the sustainable land use planning and development. Habitat International, 33(1), 15-25. http://dx.doi.org/10.1016/j.habitatint.2008.02.004

$\mathrm{Su}$, J. P. (2009). Research on the statistical monitoring system of Wuhan City Circle comprehensive reform pilot on two types of social construction. Study and Practice, 11(4), 147-152.

Sui, D. Z., \& Zeng, H. (2001). Modeling the dynamics of landscape structure in Asia's emerging desakota regions: a case study in Shenzhen. Landscape and Urban Planning, 53(1), 37-52. http://dx.doi.org/10.1016/S0169-2046(00)00136-5

Tarzia, V. (2003). European Common Indicators: towards a local sustainability profile. In A. A. Grafiche (Ed.), Final Project Report. Milan: Ambiente Italia Research Institute.

Tomalty, R., Alexander, D., Anielski, M., Wilson, J., Jozsa, A., Haider, M., . . Winfield, M. (2007). The Ontario urban sustainability report, 2007. Ottawa: The Pembina Institute.

Van Dijk, M. P., \& Mingshun, Z. (2005). Sustainability indices as a tool for urban managers, evidence from four medium-sized Chinese cities. Environmental Impact Assessment Review, 25(6), 667-688. http://dx.doi.org/10.1016/j.eiar.2004.10.001

Van Herzele, A., \& Wiedemann, T. (2003). A monitoring tool for the provision of accessible and attractive urban

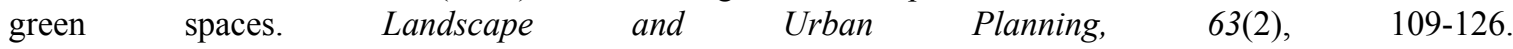
http://dx.doi.org/10.1016/S0169-2046(02)00192-5

Wang, M. L. (2008). Research on the Harmony Degree of Economic Development Transformation. Journal of Henan Normal University (Social Science), 35(6), 70-73.

Warner, J. B. (2006). The Jacksonville, Florida, Experience Community Quality-of-Life Indicators (pp. 1-22). Springer. http://dx.doi.org/10.1007/978-1-4020-4625-4_1

WCED, U. (1987). Our common future. Oxford: Oxford University Press.

Weida, K. (2005). A Study on the Relationship Between Housing Pricing and Land Pricing: Basic Model and Evidence from China. Finance \& Trade Economics, 25(11), 56-63.

Wen, H. Z., \& Goodman, A. C. (2013). Relationship between urban land price and housing price: Evidence from 21 provincial capitals in China. Habitat International, 40, 9-17. http://dx.doi.org/10.1016/j.habitatint.2013.01.004

Weng, Q. (2002). Land use change analysis in the Zhujiang Delta of China using satellite remote sensing, GIS and stochastic modelling. Journal of Environmental Management, 64(3), 273-284. http://dx.doi.org/10.1006/jema.2001.0509

Williams, K. (2000). Does intensifying cities make them more sustainable. Achieving sustainable urban form, 30-45.

Xi, Y. M., \& Wang, Y. L. (1989). Harmony theory. Journal of Systems Engineering, 4(2), 79-89.

Xiao, J., Shen, Y., Ge, J., Tateishi, R., Tang, C., Liang, Y., \& Huang, Z. (2006). Evaluating urban expansion and land use change in Shijiazhuang, China, by using GIS and remote sensing. Landscape and Urban Planning, 75(1), 69-80. http://dx.doi.org/10.1016/j.landurbplan.2004.12.005

Xing, Y., Horner, R. M. W., El-Haram, M. A., \& Bebbington, J. (2009). A framework model for assessing sustainability impacts of urban development. Accounting Forum, 33(3), 209-224. http://dx.doi.org/10.1016/j.accfor.2008.09.003

Xiong, Y., Wen, X. M., \& Guo, X. (2006). Study on the Land Utilization and Urbanization Development in Hunan Province. Economic Geography, 26(6), 1042-1046. 
Ye, W. H., Chen, G. Q., \& Tu, Y. G. (1999). Harmony: the soul of Sustainable Development. China Population Resources and Environment, 9(4), 1-4.

Yeh, T. M., \& Chen, S. H. (2014). Integrating Refined Kano Model, Quality Function Deployment, and Grey Relational Analysis to Improve Service Quality of Nursing Homes. Human Factors and Ergonomics in Manufacturing \& Service Industries, 24(2), 172-191. http://dx.doi.org/10.1002/hfm.20358

Yin, K. D., \& Li, P. (2011). Study on the Harmony Degree of Economic Development Between Land and Sea in Coastal Provinces. Statistics and Decision, 21(6), 116-118.

Yin, L., Feng, B., \& Li, S. (2012). Regional development disparities and spatial pattern evolution in guangdong province. Areal Research and Development, 31(1), 30-34.

Zhang, Q., Xing, H., Liu, F., \& Huang, Y. (2014). An enhanced grey relational analysis method for interval-valued intuitionistic fuzzy multiattribute decision making. Journal of Intelligent and Fuzzy Systems, 26(1), 317-326.

Zhang, X., Wu, Y., \& Shen, L. (2011). An evaluation framework for the sustainability of urban land use: A study of capital cities and municipalities in China. Habitat International, 35(1), 141-149. http://dx.doi.org/10.1016/j.habitatint.2010.06.006

\section{Appendix A}

The basic social and economic statistic data of Wuhan Metropolitan Area in 2012

Table A. Basic social and economic statistic data of Wuhan Metropolitan Area (2012)

\begin{tabular}{|c|c|c|c|c|c|}
\hline Item & $\begin{array}{l}\text { Land } \quad \text { area } \\
(\mathrm{sq} \cdot \mathrm{km})\end{array}$ & $\begin{array}{l}\text { Population of } \\
\text { permanent } \\
\text { residents }\end{array}$ & $\begin{array}{l}\text { Urbanization rate } \\
(\%)\end{array}$ & $\begin{array}{l}\text { Cultivated.area.at } \\
\text { year end. } \\
(1000 \text { hectares })\end{array}$ & $\begin{array}{l}\text { Investment in } \\
\text { Fixed Assets (100 } \\
\text { million yuan) } \\
\end{array}$ \\
\hline Wuhan & 9051.27 & 1022 & 77 & 199.44 & 5974.53 \\
\hline Huangshi & 4583 & 244.07 & 60.4 & 89.57 & 750.25 \\
\hline Ezhou & 1594 & 105.35 & 62.9 & 40.55 & 450.01 \\
\hline Xiaogan & 8910 & 483.31 & 49.6 & 262.31 & 980.82 \\
\hline Huanggang & 17446 & 623.19 & 39.35 & 343.48 & 1102.94 \\
\hline Xianning & 9861 & 247.5 & 53.4 & 156.59 & 756.28 \\
\hline Xiantao & 2538 & 118.49 & 60 & 90.54 & 241.33 \\
\hline Qianjiang & 2004 & 95.04 & 48.51 & 72.08 & 237.06 \\
\hline Tianmen & 2622 & 133.9 & 47.08 & 109.80 & 210.99 \\
\hline Item & $\begin{array}{l}\text { Investment in } \\
\text { Real Estate (100 } \\
\text { million yuan) }\end{array}$ & $\begin{array}{l}\text { Financial } \\
\text { revenue } \\
(100 \text { million } \\
\text { yuan })\end{array}$ & $\begin{array}{l}\text { Comprehensive } \\
\text { land price (Yuan) }\end{array}$ & $\begin{array}{l}\text { GDP } \quad \text { (100.million } \\
\text { yuan) }\end{array}$ & $\begin{array}{l}\text { Share of primary, } \\
\text { Secondary and } \\
\text { Tertiary industries }\end{array}$ \\
\hline Wuhan & 1905.6 & 978.52 & 3109 & 8003.82 & 4:48:48 \\
\hline Huangshi & 56.04 & 65.84 & 606.05 & 1040.95 & $8: 62: 30$ \\
\hline Ezhou & 11.65 & 33.02 & 879 & 560.39 & $12: 60: 28$ \\
\hline Xiaogan & 74.95 & 69.5 & 707.56 & 1105.16 & $28: 40: 32$ \\
\hline Huanggang & 15376 & 62.92 & 684 & 1192.88 & $27: 40: 33$ \\
\hline Xianning & 84.96 & 45.82 & 495 & 773.20 & $19: 48: 33$ \\
\hline xiantao & 15.66 & 17.14 & 600 & 444.20 & $16: 52: 32$ \\
\hline Qianjiang & 9.15 & 16.02 & 850 & 441.76 & $14: 59: 27$ \\
\hline Tianmen & 14.9 & 11.00 & 785.97 & 321.22 & $21: 51: 28$ \\
\hline
\end{tabular}




\section{Copyrights}

Copyright for this article is retained by the author(s), with first publication rights granted to the journal.

This is an open-access article distributed under the terms and conditions of the Creative Commons Attribution license (http://creativecommons.org/licenses/by/3.0/). 